\title{
$N$-Heterocyclic Carbene-Platinum Complexes Featuring an Anthracenyl Moiety: Anti-Cancer Activity and DNA Interaction
}

\author{
Sébastien Harlepp ${ }^{1,2, *}$, Edith Chardon ${ }^{2}$, Mathilde Bouché ${ }^{2}\left(\mathbb{0}\right.$, Georges Dahm ${ }^{2}$, \\ Mounir Maaloum ${ }^{2,3}$ and Stéphane Bellemin-Laponnaz ${ }^{2, *(D)}$ \\ 1 INSERM UMR_S1109, Centre de Recherche d'Immunologie et d'Hématologie, \\ 67085 Strasbourg CEDEX, France \\ 2 Institut de Physique et Chimie des Matériaux de Strasbourg, Université de Strasbourg, \\ 67034 Strasbourg, France \\ 3 Institut Charles Sadron, 23 rue du Loess, 67000 Strasbourg, France \\ * Correspondence: harlepp@unistra.fr (S.H.); bellemin@unistra.fr (S.B.-L.); \\ Tel.: +33-36-885-404 (S.H.); +33-388-107-166 (S.B.-L.)
}

Received: 17 July 2019; Accepted: 22 August 2019; Published: 27 August 2019

\begin{abstract}
A platinum (II) complex stabilized by a pyridine and an N-heterocyclic carbene ligand featuring an anthracenyl moiety was prepared. The compound was fully characterized and its molecular structure was determined by single-crystal X-ray diffraction. The compound demonstrated high in vitro antiproliferative activities against cancer cell lines with $\mathrm{IC}_{50}$ ranging from 10 to $80 \mathrm{nM}$. The presence of the anthracenyl moiety on the N-heterocyclic carbene (NHC) Pt complex was used as a luminescent tag to probe the metal interaction with the nucleobases of the DNA through a pyridine-nucleobase ligand exchange. Such interaction of the platinum complex with DNA was corroborated by optical tweezers techniques and liquid phase atomic force microscopy (AFM). The results revealed a two-state interaction between the platinum complex and the DNA strands. This two-state behavior was quantified from the different experiments due to contour length variations. At $24 \mathrm{~h}$ incubation, the stretching curves revealed multiple structural breakages, and AFM imaging revealed a highly compact and dense structure of platinum complexes bridging the DNA strands.
\end{abstract}

Keywords: antitumoral activity; platinum; N-heterocyclic carbene; two-state interaction; AFM and optical tweezers microscopy

\section{Introduction}

Inorganic compounds have an enormous impact in medicine, particularly in the treatment of cancer. Since Rosenberg's [1,2] discovery of the cytotoxicity of cisplatin, it has found wide use as a chemotherapeutic in clinics and cisplatin continues to be used in $50-70 \%$ of all patients suffering cancer, usually administered with other drugs in combination therapy [3]. It is especially effective in treating testicular [4] and ovarian [5] carcinoma but is also used to treat other types of cancers [6]. Although the use of cisplatin in clinics has been a breakthrough in the treatment of cancer, it still faces limitations. In addition of exhibiting high systemic toxicity leading to significant side-effects $[7,8]$ that can be minimized by dose adjustment $[9,10]$, it is inactive against many cancer cell lines and metastases (secondary cancers).

An alternative to cisplatin could be proposed by using either other metallic compounds or by modifying the nature of the side groups. In that respect, N-heterocyclic carbenes (NHC) $[11,12]$ have become privileged ligands in coordination chemistry $[13,14]$ finding multiple applications ranging from homogeneous catalysis to material science [15-23]. More recently, these systems have also been 
studied in medicinal chemistry with promising successes [24-28]. Indeed, the use of N-heterocyclic carbene ligands offers new opportunities for biological applications in part thanks to their ease of derivatization and the high stability of their corresponding metal complexes. Apart from the antimicrobial properties demonstrated by various gold(I) [29,30], silver(I) [31-37], ruthenium(II), and rhodium(I) derivatives [38,39], N-heterocyclic carbene transition metal complexes have also demonstrated promising results as anticancer agents. Several NHC complexes have been studied as anticancer metallodrug candidates, especially gold [40-43], silver [44,45], palladium [46,47], and platinum $[48,49]$, displaying antitumor activities through multiple cytotoxicity mechanisms. Among these metals, the development of platinum-based complexes bearing novel ligands is a hot topic to overcome the severe limitations encountered with the use of the world's bestselling anticancer drug cisplatin, e.g., systemic toxicities sometimes accompanied by acquired cell-resistance mechanisms during the treatment.

It has been demonstrated that with NHCs, encouraging results were obtained with N-heterocyclic carbene trans-configured complexes of general formula $(\mathrm{NHC}) \mathrm{Pt}_{2}(\mathrm{~L})(\mathrm{X}=$ halogen, $\mathrm{L}=$ nitrogencontaining ligand, Figure 1) $[48,49]$. Such complexes are highly effective as anticancer agents against various cancer cell lines, including cisplatin-resistant cells [50]. They usually exhibit cytotoxic activities with $\mathrm{IC}_{50}$ at a micromolar range and most of them outperform cisplatin.

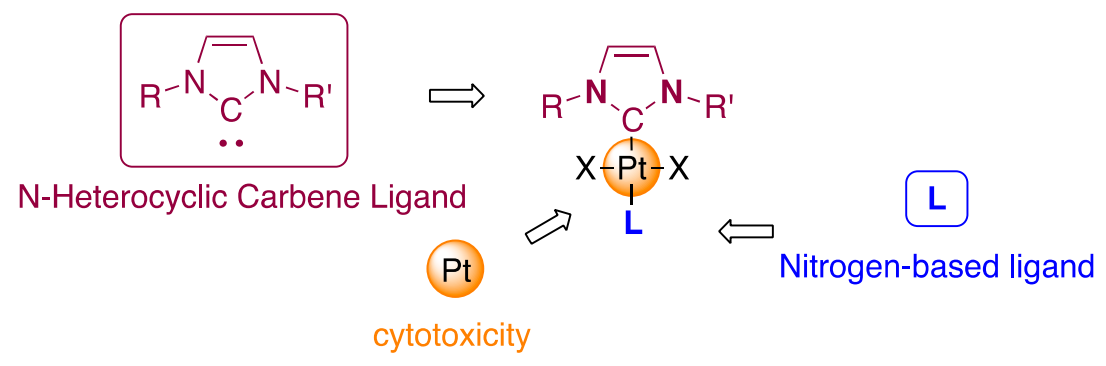

Figure 1. Chemical structures of platinum N-heterocyclic carbene (NHC) complexes that show high cytotoxic activities against cancer cells.

Tremendous efforts have been dedicated to understand the mechanism of cytotoxicity of cisplatin $\left[\mathrm{Pt}\left(\mathrm{NH}_{3}\right)_{2} \mathrm{Cl}_{2}\right]$ [51], and DNA has been suggested as the main intracellular target of such Pt-based antitumor agent [52]. The mechanism is proposed to involve DNA binding of the platinum center [50], causing DNA binding and cell cycle arrest, which ultimately triggers programmed cell death (apoptosis). In the case of cisplatin, the complex is hydrolyzed and the two chloride anions are exchanged by two molecules of water. When the aqueous cisplatin interacts with DNA, the water molecules are easily exchanged by the N7 atoms of guanine (or adenine) to form adducts. The cisplatin-DNA adducts are mostly intrastrand crosslinks as well as interstrand crosslinks [53]. Notably, cisplatin is also able to significantly distort the double helix toward the major groove but also to induce a partial unwinding in the proximity of adducts sites.

On the other hand, little is known about the intracellular cytotoxic mechanism of NHC-Pt complexes mainly due to their novelty [54,55]. We thus decided to conduct several studies on the interaction between DNA and such type of complexes. For this purpose, we selected platinum complex 1 (NHC)PtI 2 (pyridine) (Figure 2), and we also used a related complex (complex 2) to evidence the interaction of NHC-Pt complex with DNA by means of luminescence Fluorescent Resonance Energy Transfer (FRET) studies.

In this paper, we evaluated the biological activity of complex 1 and then investigated with optical tweezers and atomic force microscopy (AFM) the elastic behavior of single DNA molecules interacting with the platinum-based molecule. We show that this compound effectively decreases the contour length of DNA and induces DNA compaction. Interestingly, in comparison with cisplatin, this complex has an enhanced ability to shorten DNA at low concentrations. 

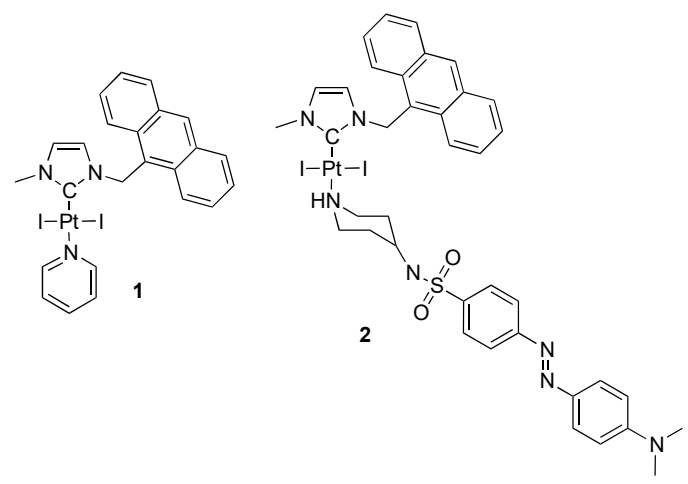

Figure 2. Molecular structure of the NHC platinum complexes used in this study.

\section{Results}

\subsection{Molecular Structure of Complex $\mathbf{1}$ and Antiproliferative Activities}

Suitable crystals of complex 1 for X-ray diffraction studies were obtained from $\mathrm{CH}_{2} \mathrm{Cl}_{2} / n$-hexane. Figure 3 displays the molecular structure of the compound along with selected bond and geometrical parameters. A summary of crystal and refinement data is included in supporting information. The complex displays the coordination of the pyridine ligand trans to the N-heterocyclic carbene ligand with the expected square-planar geometry at the platinum center. The two iodide ligands adopt the trans geometry [I-Pt-I angle of $172.401(14)^{\circ}$ ] and point perpendicularly toward the NHC ligand plane $[\mathrm{N}(2)-\mathrm{C}(1)-\mathrm{Pt}(1)-\mathrm{I}(1), 87.9(3)]$ and the pyridine plane. The carbene-platinum and the platinum-N bond distances were found to be 1.961(4) $\AA$ and 2.088(3) $\AA$, respectively, thus illustrating the strong trans effect of the $\sigma$-donor NHC ligand.

The in vitro antiproliferative activity on tumor cells of the NHC platinum complex $\mathbf{1}$ was evaluated by MTS colorimetric assay against a panel of 4 cancer cell lines, namely MCF7 (breast carcinoma), HCT116 (colon cancer cells), PC3 (prostate adenocarcinoma), and SKOV3 (ovarian cancer cells) along with 2 noncancer cells MRC-5 (human fetal lung fibroblast cells) and EPC (endothelial progenitor cells). $\mathrm{IC}_{50}$ values are summarized in Table 1 (in $\mu \mathrm{M}$ ). Overall, these biological assays revealed that the platinum complex exhibits very high cytotoxic activity below the micromolar range. The $\mathrm{IC}_{50}$ values are ranging from $0.01 \mu \mathrm{M}$ to $0.08 \mu \mathrm{M}$. The average reactivity of this compound is, therefore, of two orders of magnitude higher on average compared to cisplatin, which has been used as reference.

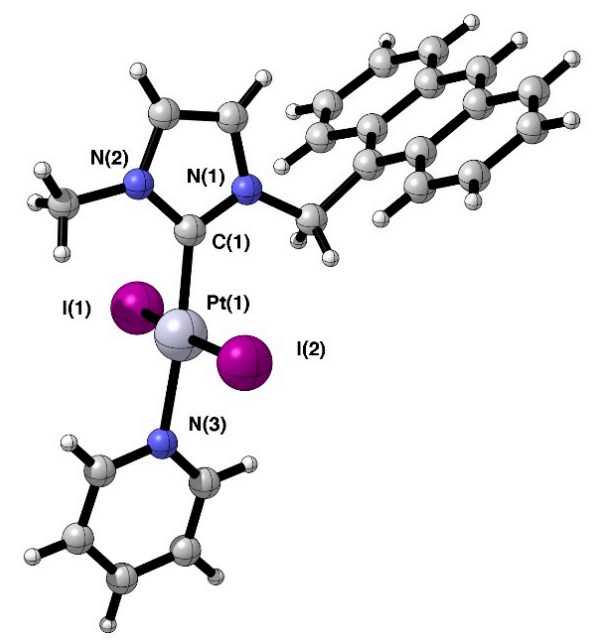

Figure 3. Molecular structure of the platinum complex 1. Selected bond lengths $(\AA)$ and angles $\left({ }^{\circ}\right): \quad \mathrm{C}(1)-\mathrm{Pt}(1), 1.961(1) ; \quad \mathrm{N}(3)-\mathrm{Pt}(1), 2.088(3) ; \quad \operatorname{Pt}(1)-\mathrm{I}(1), 2.5732(3) ; \quad \operatorname{Pt}(1)-\mathrm{I}(2), 2.6013(3)$; C(1)-Pt(1)-N(3), 174.88(14); C(1)-Pt(1)-I(1); 87.72(10); C(1)-Pt(1)-I(2), 92.03(10); I(1)-Pt(1)-I(2), 172.401(14); $\mathrm{N}(1)-\mathrm{C}(1)-\mathrm{Pt}(1)-\mathrm{I}(1),-88.3(3) ; \mathrm{N}(2)-\mathrm{C}(1)-\mathrm{Pt}(1)-\mathrm{I}(1), 87.9(3)$. 
Table 1. In vitro cytotoxic activity of platinum complex $\mathbf{1}$ against several cell lines (after $72 \mathrm{~h}$ of incubation; stock solutions in DMSO for complex 1; stock solution in $\mathrm{H}_{2} \mathrm{O}$ for cisplatin); values in $\mu \mathrm{M}$.

\begin{tabular}{ccccccc}
\hline Compound & MCF7 & HCT116 & PC3 & SK-OV3 & MRC-5 & EPC \\
\hline 1 & $0.08 \pm 0.01$ & $0.01 \pm 0.01$ & $0.03 \pm 0.01$ & $0.02 \pm 0.01$ & $0.02 \pm 0.01$ & $0.08 \pm 0.01$ \\
Cisplatin & $>10$ & $3.3 \pm 0.1$ & $5.1 \pm 0.4$ & $4.4 \pm 0.8$ & $8.5 \pm 0.1$ & $2.2 \pm 0.1$ \\
Reactivity Ratio & $>125$ & 330 & 170 & 220 & 425 & 27.5 \\
\hline
\end{tabular}

MCF7, breast carcinoma. HCT-116, colon cancer cells. PC3, prostate adenocarcinoma. SKOV3, ovarian cancer cells. MRC-5, human fetus cell line. EPC, endothelial progenitor cells.

\subsection{Contour Length Behavior at the Single DNA Molecule Level in Interaction with Platinum Complex 1}

To shed light on the molecular interaction between the platinum compound and DNA, we performed sets of single-molecule experiments. With the use of optical tweezers, mechanical behavior at the molecular level can be evidenced. These mechanical behaviors are directly linked to the molecular interaction of DNA with the added drug [56-58]. Before adding the platinum compound, we first checked the force-extension curve of naked DNA molecules and adjusted the resulting curves with the modified Marko-Siggia Worm-like Chain model described in Wang et al. [59]. Then, to follow the kinetics, we injected into the flow cell, a solution containing $1 \mu \mathrm{M}$ of platinum compound $\left(1 \mathrm{DNA}_{\mathrm{bp}}\right.$ for 200 drug molecules) and investigated its effect on DNA. By moving the piezoelectric stage, we stretched DNA to the force-induced melting plateau and then relaxed it to its initial position (Figure 4A).
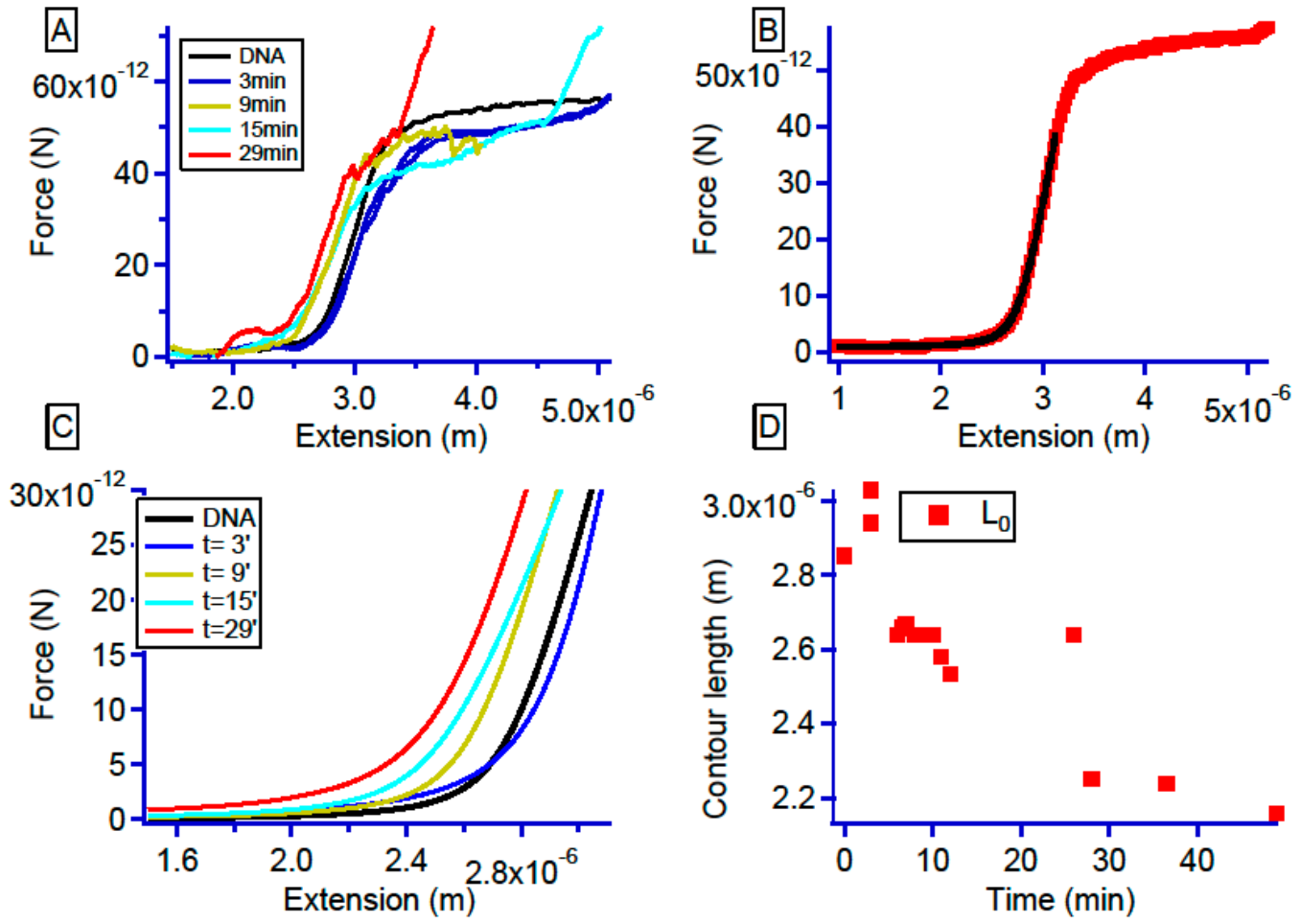

Figure 4. (A) DNA-platinum complex force-extension curves evolution at different incubation time. The curves evolve from the raw DNA (black) curve, to short time range around 3 min where DNA length increases (dark blue) before it decreases continuously over longer times (gold, light blue, and red). (B) Raw DNA stretching curve (red) with the modified Marko-Siggia WLC model (black). The adjusting parameters in that case are for the contour length $\mathrm{L}_{0}=2.87 \mu \mathrm{m}$ and for the persistence length $\mathrm{L}_{\mathrm{p}}=40 \mathrm{~nm}$ in good agreement with the tabulated values. (C) For more clarity, the fit obtained from the curves represented in the panel A with the same color codes. (D) Contour length of the DNA molecules as a function of time. The length after $3 \mathrm{~min}$ is $3.1 \mu \mathrm{m}$ this length the decreases from 2.7 to $2.24 \mu \mathrm{m}$ after 29 min of incubation. 
For pure DNA stretching, after adjusting the Worm Like Chain (WLC) model, we got an average length over tens of curves of $2.85( \pm 0.1) \mu \mathrm{m}$ and a persistence length of $48( \pm 8) \mathrm{nm}$ (Figure $4 \mathrm{~B})$. These values are in good agreement with the expected values due to our salt conditions. After introduction of the platinum complex, we continued to perform stretching on the DNA molecule. Surprisingly, the general behavior represented in Figure $4 \mathrm{~A}$ was not monotonous. Figure $4 \mathrm{C}$ shows how the mechanical response of the DNA-Pt adducts evolves over time. Past the first $5 \mathrm{~min}$, the contour length of the DNA molecule increased from $2.85 \mu \mathrm{m}$ to $3.1( \pm 0.2) \mu \mathrm{m}$. This $9 \%$ size increase was then followed by a continuous decrease in size from 3.1 to $2.64 \mu \mathrm{m}$ ( $\pm 7 \%$ of length decrease from the initial length).

To confirm this result and get better insights on the observed behavior we used atomic force microscopy to visualize the general trend of the molecular transition observed with the optical tweezers. Figure 5 shows the images obtained with the AFM. From these images acquired at different time points, we extracted the contour length by summing the different segment lengths (Figure 5 panel a). The different lengths obtained over time are represented on the main graph in Figure 5. Again, one can observe at short times (around $5 \mathrm{~min}$ ) that the contour length of the DNA increases before a decrease over time. These two methods confirm this 2-state behavior in the interaction. On the different panels ( $b$ to $d$ ), one can also observe that the number of crossings increases over time. One can hypothesize that this platinum complex induces interstrand bounds. Nevertheless, if we compare panel a (pure DNA) to panel $b$ and panel $d$, not only the number of crosslink changes but also the number of kinks on the DNA strands. On panel a, the DNA molecule changes orientation with smooth angles, whereas on panel $\mathrm{d}$ the reorientations are abrupt with angles close to $70^{\circ}$ on small distances.

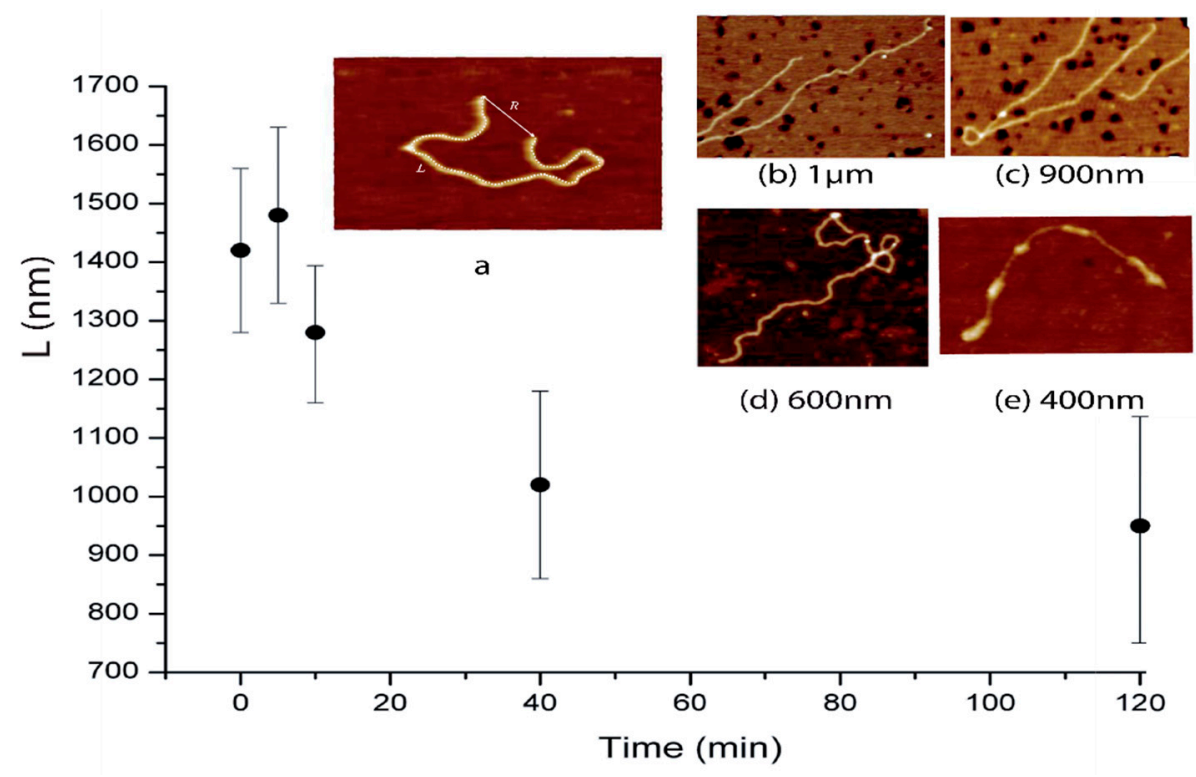

Figure 5. DNA length extracted from the atomic force microscopy (AFM) images as a function of platinum complex incubation time. The contour length $\mathrm{L}$ increases rapidly after 5 min before a continuous decrease. The image shows the DNA (a) conformations and length at (b) 5, (c) 10, (d) $40 \mathrm{~min}$, and (e) $20 \mathrm{~h}$. The sizes on bottom of the images represent the horizontal full scale of the images represented.

These observations extracted from both experiments, suggest a 2-state interaction to occur. The first state consists of a length increase of the DNA molecule. Usually, this increase is attributed to intercalation of aromatic compounds into the base stacking [57]. Even if we do not have full evidence of this intercalation, we hypothesize that in our case anthracene could play this role. The second state is a condensation of the DNA molecule with an apparent shorter contour length. In the case of cisplatin, this corresponds to the intra and interstrand reactions [60]. 
Putting these 2 behaviors together (even if intercalation is of full evidence) as chemical reactions we get following:

$$
\left\{\begin{array}{c}
{[\mathrm{D}]+[\mathrm{Pt}] \underset{\mathrm{k}_{2}}{\rightleftharpoons} \mathrm{D}_{\mathrm{k}_{1}}^{\mathrm{k}_{1}}[\mathrm{DPt}]_{\mathrm{i}}} \\
{[\mathrm{DPt}]_{\mathrm{i}} \rightleftharpoons \mathrm{k}_{4}} \\
\mathrm{k}_{3}[\mathrm{DPt}]_{\mathrm{A}}
\end{array}\right.
$$

where D stands for DNA base pairs, $[\mathrm{DPt}]_{\mathrm{i}}$ stands for the "intercalated" DNA and $[\mathrm{DPt}]_{\mathrm{A}}$ stands for the DNA platinum condensed form.

One can write the kinetic reaction and the initial conditions for that system:

$$
\left\{\begin{array}{l}
\frac{\partial}{\partial \mathrm{t}}[\mathrm{D}]=-\mathrm{k}_{1}[\mathrm{D}][\mathrm{Pt}]+\mathrm{k}_{2}[\mathrm{DPt}]_{\mathrm{i}} \\
\frac{\partial}{\partial \mathrm{t}}[\mathrm{DPt}]_{\mathrm{i}}=\mathrm{k}_{1}[\mathrm{D}][\mathrm{Pt}]-\left(\mathrm{k}_{2}+\mathrm{k}_{3}\right)[\mathrm{DPt}]_{\mathrm{i}}+\mathrm{k}_{4}[\mathrm{DPt}]_{\mathrm{a}^{\prime}} \\
\frac{\partial}{\partial \mathrm{t}}[\mathrm{DPt}]_{\mathrm{a}}=-\mathrm{k}_{4}[\mathrm{DPt}]_{\mathrm{a}}+\mathrm{k}_{3}[\mathrm{DPt}]_{\mathrm{i}^{\prime}} \\
\frac{[\mathrm{Pt}]}{[\mathrm{DNA}]_{0}}=\text { ratio, } \\
{[\mathrm{D}]_{0}=10^{-9}} \\
{[\mathrm{DPt}]_{\mathrm{i} 0}=[\mathrm{DPt}] \mathrm{a} 0=0}
\end{array}\right.
$$

We solved these equations using Wolfram Mathematica software. The kinetic parameters used to solve the equations were found from previous works and summarized in Table 2. Usually, people perform titrations and thus, only the thermodynamic constants are reported. Nevertheless, this dissociation constant is linked to the kinetic constants in the following way:

$$
\mathrm{K}_{\mathrm{d}}=\frac{\mathrm{k}_{\mathrm{off}}}{\mathrm{k}_{\mathrm{on}}}
$$

where $K_{d}$ stands for the dissociation constant, $k_{\text {on }}$ for the kinetic constant in the direction of the expected reaction and $\mathrm{k}_{\text {off }}$ the kinetic constant in the opposite direction.

Table 2. Different kinetic constants values used in the simulation, values from the literature.

\begin{tabular}{ccc}
\hline Name & Value Literature & Reference \\
\hline $\mathrm{K}_{\mathrm{d}}=8 \mu \mathrm{M}$ & $0.35<\mathrm{K}_{\mathrm{d}}<26 \mu \mathrm{M}$ & {$[61-63]$} \\
$\mathrm{k}_{1}=0.025 \mathrm{M}^{-1} \cdot \mathrm{min}^{-1}$ & & {$[60,64]$} \\
$\mathrm{k}_{2}=2 \times 10^{-7} \mathrm{~min}^{-1}$ & $\mathrm{~K}_{\mathrm{d}}$ corresponds \\
$\mathrm{k}_{3}=0.055 \mathrm{M}^{-1} \cdot \mathrm{min}^{-1}$ & $57<\mathrm{k}<8 \times 10^{-3} \mathrm{M}^{-1} \cdot \mathrm{min}^{-1}$ & {$[65]$} \\
$\mathrm{k}_{4}=5 \times 10^{-9} \mathrm{~min}^{-1}$ & Adjusted from experiment \\
$\mathrm{K}_{\mathrm{d}}=2.57 \times 10^{-8} \mathrm{M}$ & $\mathrm{K}_{\mathrm{d}}=10^{-8} \mathrm{M}$ & {$[66,67]$} \\
\hline
\end{tabular}

No further adjustments were operated except taking into account the relative concentrations of the different compounds used for the different experiments performed.

To obtain the relative concentrations of the different products over time, all the constants have to be multiplied by $\mathrm{D}[0]$, whereas the concentrations have to be divided by $\mathrm{D}[0]$. $\mathrm{D}[0$ ] corresponds to the initial DNA concentration. The measured parameter is the contour length of the DNA molecule. We have to assume a linear distribution in length of the molecule depending on the ratio of the products formed. The equation obtained with that assumption is:

$$
\left\{\begin{array}{l}
\mathrm{L}_{\mathrm{DNA}}(\mathrm{t})=\alpha * \mathrm{~L}_{\mathrm{dsDNA}}(\mathrm{t})+\beta * \mathrm{~L}_{\mathrm{DNA}_{\mathrm{i}}}(\mathrm{t})+\gamma * \mathrm{~L}_{\mathrm{DNA}_{\mathrm{a}}}(\mathrm{t}) \\
\alpha+\beta+\gamma=1
\end{array}\right.
$$

where $\alpha, \beta$, and $\gamma$ represent the ratios of dsDNA, intercalated DNA, and complexed DNA, respectively, from the kinetic equations and $\mathrm{L}_{\mathrm{dsDNA}}$ is the length of the double-stranded DNA $=0.34 \mathrm{~nm}, \mathrm{~L}_{\mathrm{DNAi}}$ the intercalated length $=0.37 \mathrm{~nm}$, and $\mathrm{L}_{\mathrm{DNAa}}$ the complexed DNA length $=0.22 \mathrm{~nm}$. These lengths were extracted from the experimental results obtained with AFM and the optical tweezers. As can be seen 
in Table 1, the reactivity of the molecule is around 200 times higher than the one obtained for cisplatin, taking into account this value and the relative concentrations of the product used.

\subsection{Luminescence Studies to Understand the Underlying Interactions}

To shed light on these two assumptions (intercalation followed by condensation), luminescent studies were performed. First of all, we have to determine whether the ligand located trans to the NHC carbene is labile in contact with DNA and thus allows metal-DNA interactions. To show this effect, we used molecule 2 (Figure 2), which contains a dabsyl moiety used as a 'dark quencher' when bound on the Pt metal [68]. After addition of dsDNA in solution, the luminescence was recorded over time. A slight evolution (Figure 6) was observed after $5 \mathrm{~h}$ of reaction at room temperature. Nevertheless, a significant increase of the luminescence was observed after prolonged heating at $40{ }^{\circ} \mathrm{C}$ for four days. Such result indicates a release of the dark quencher from the platinum which is most likely due to the formation of a DNA-NHC-platinum adduct. The chemical reaction describing the observed behavior is also shown in Figure 6. Nevertheless, this chemical reaction does not allow showing the release of one of the iodine ligand in order to create a compaction-reactive product as it is described in the chemical reactions described above (Equation (1)).

(a)

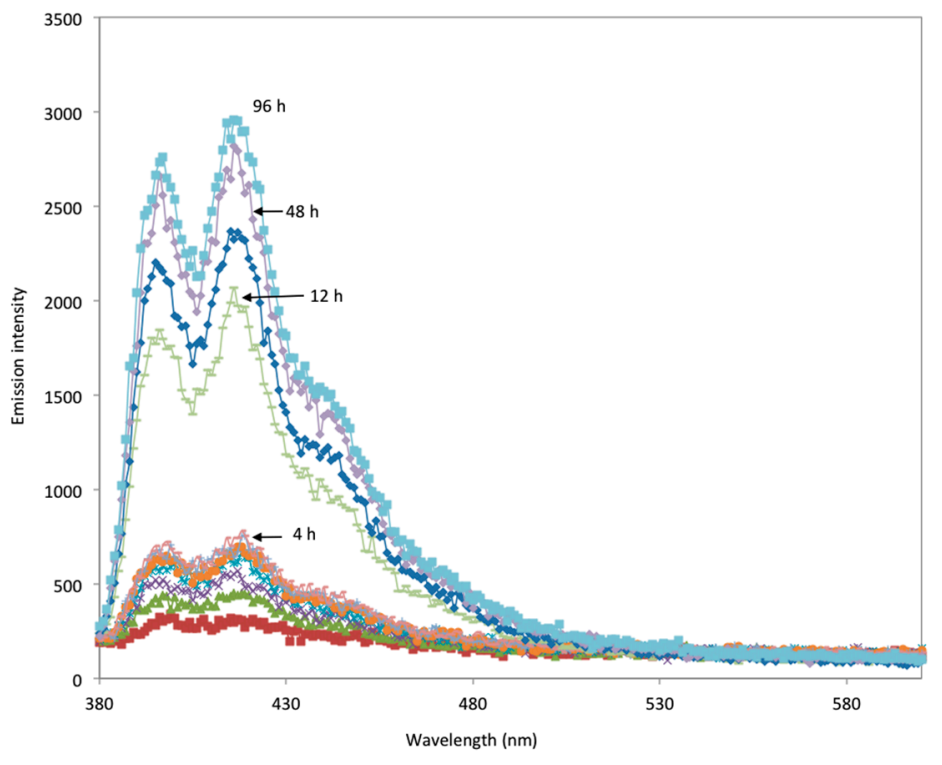

(b)

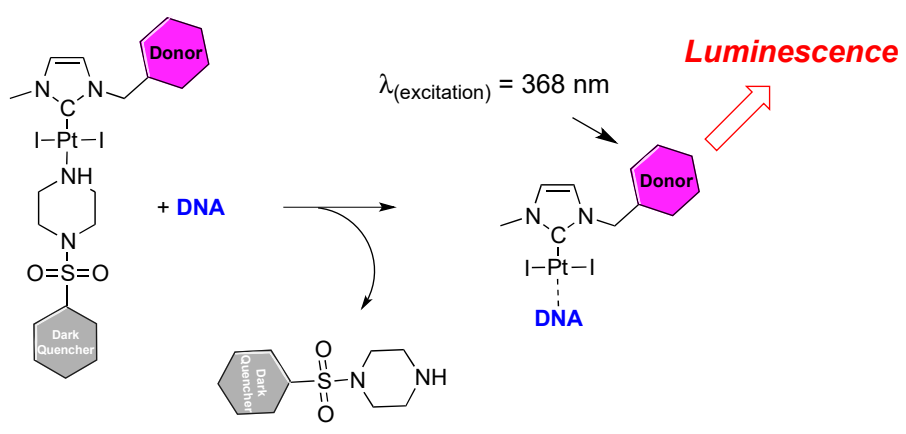

Figure 6. (a) Measurements of the emission spectra after excitation at $\lambda=368 \mathrm{~nm}(0.29 \mathrm{mg}$ of 2 were dissolved in $50 \mu \mathrm{L}$ of DMSO and added to a solution of $1.8 \mathrm{mg}$ of salmon sperm DNA in water $(1.950 \mathrm{~mL}), \mathrm{C}_{\mathrm{Pt}}=1.34 \times 10^{-4},(10$ base pairs compared to $\left.\mathrm{Pt})\right)$. $(\mathbf{b})$ Origin or the luminescence upon interaction with DNA (50).

To show that our compound can intercalate into the DNA base pairs, luminescent studies were performed on complex 1 in interaction with DNA. First, the platinum complex is excited at $360 \mathrm{~nm}$, 
and luminescence is acquired from 400 to $450 \mathrm{~nm}$ (red curve on Figure 7A). Later the experiments are performed with a mix of DNA and this compound at 2 different ratios over time. The two ratios are 100 platinum complexes (black curves in Figure 7A) per DNA base pair and 10 platinum complexes over DNA base pairs (blue curves in Figure 7A). The first curve was recorded around 3 min after the addition of the platinum compounds and all other curves at a ten minutes later time point.
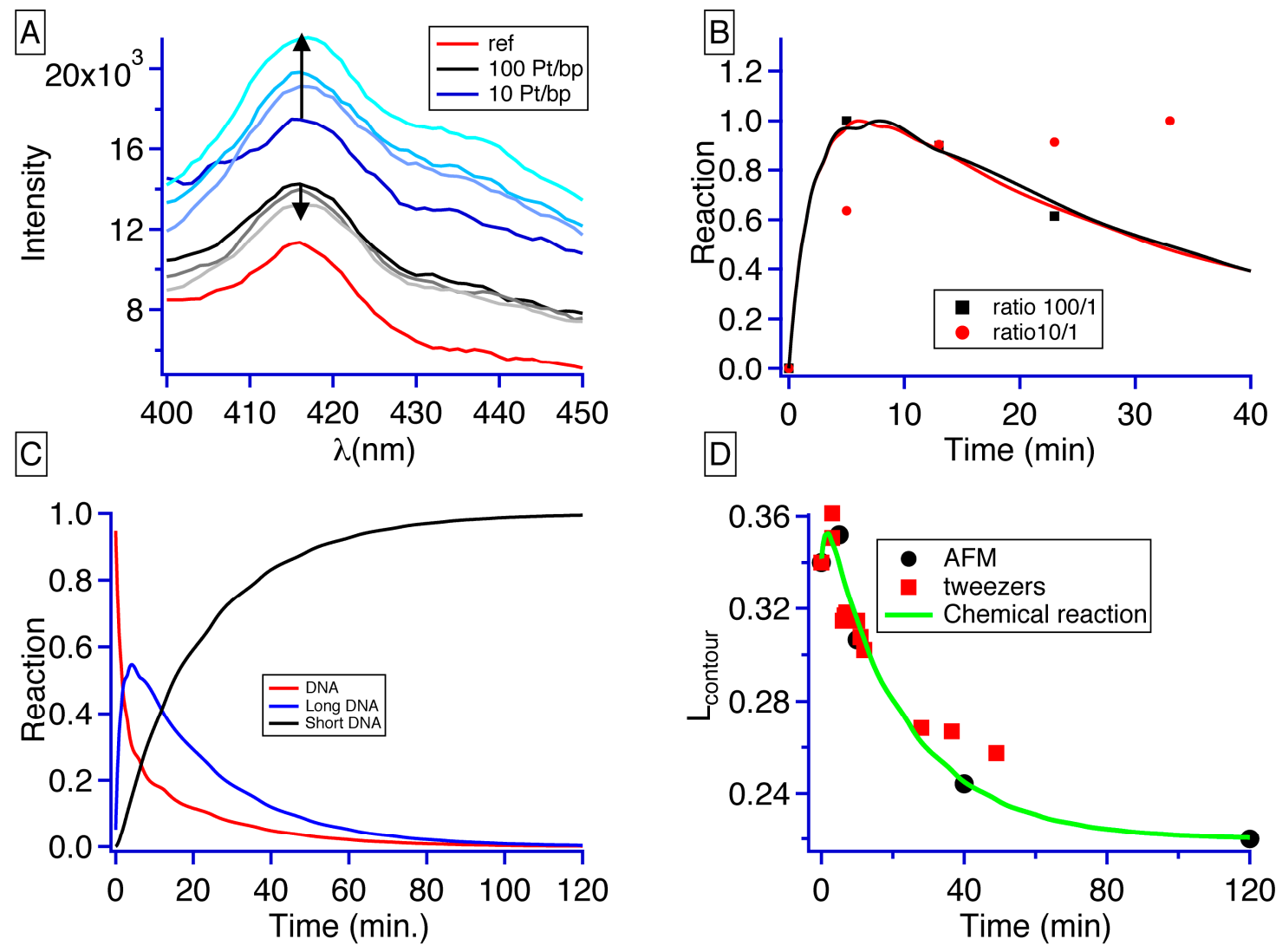

Figure 7. (A) Luminescence studies on the interaction between DNA and platinum. Two ratios were used in this study. The black curves represent the $100 \mathrm{Pt} / \mathrm{bp}$ ratio whereas the blue ones represent the $10 \mathrm{Pt} / \mathrm{bp}$ ratio. Time evolution is represented by the color gradient that varies from dark to light colors. The time schedule varies as follow darkest curve is 1 min of incubation, then 10,20, and 30 min are represented. (B) The dots represent the evolution of the normalized maximal intensity obtained on each curve as a function of time. The lines are the normalized chemical model for the intercalation as a function of time and relative concentration. (C) Chemical evolution of the different species in solution as a function of time. (D) Evolution of the contour length as a function of time obtained with the AFM measurements (black dots), the optical tweezers (red squares) and the simulation green line.

Two different behaviors are observed. As for the ratio of 10, the luminescence increases over time (from dark blue to light blue) while the ratio of 100 continuously decreases over time (from black to light grey) (Figure 7A). From these raw luminescent curves, we took the maximal value, and for each ratio normalized these values so that the overall behavior varies from 0 to 1 (Figure 7B). The theoretical curves obtained from the resolution of the system Equation (6) were superimposed for both cases. The only parameter that was changed in these curves was the ratio. The theoretical curves adjust the experimental data points and in the case of the intercalation this model can be used.

This model allows the monitoring of all the different compounds over time (Figure 7C). For a ratio of 200, after $5 \mathrm{~min}$, DNA is totally consumed in its native form and the intercalated structure (long DNA) dominates. Around $20 \mathrm{~min}$, there is as much intercalated DNA than the adduct one. At $50 \mathrm{~min}$, the reaction reaches its steady state, the adduct DNA represents $90 \%$ of the total structure whereas the 
intercalated one represents around $10 \%$ of the global structure. Introducing this result in Equation (7), we obtain an average change in the contour length represented on the green curve in Figure 7D. On the same curve, we represented the contour length obtained from the AFM experiment and the optical tweezers experiment. The average behavior of the theoretical curve mimics nicely the experimental data points.

\subsection{Persistence Length Behavior}

From the traction curves, one can also extract a second parameter, namely the persistence length. From the AFM images it is also feasible as described in Mantelli et al. [69], using Equation (4). The comparison of these persistence lengths obtained from both experiments is summarized in Figure 8.

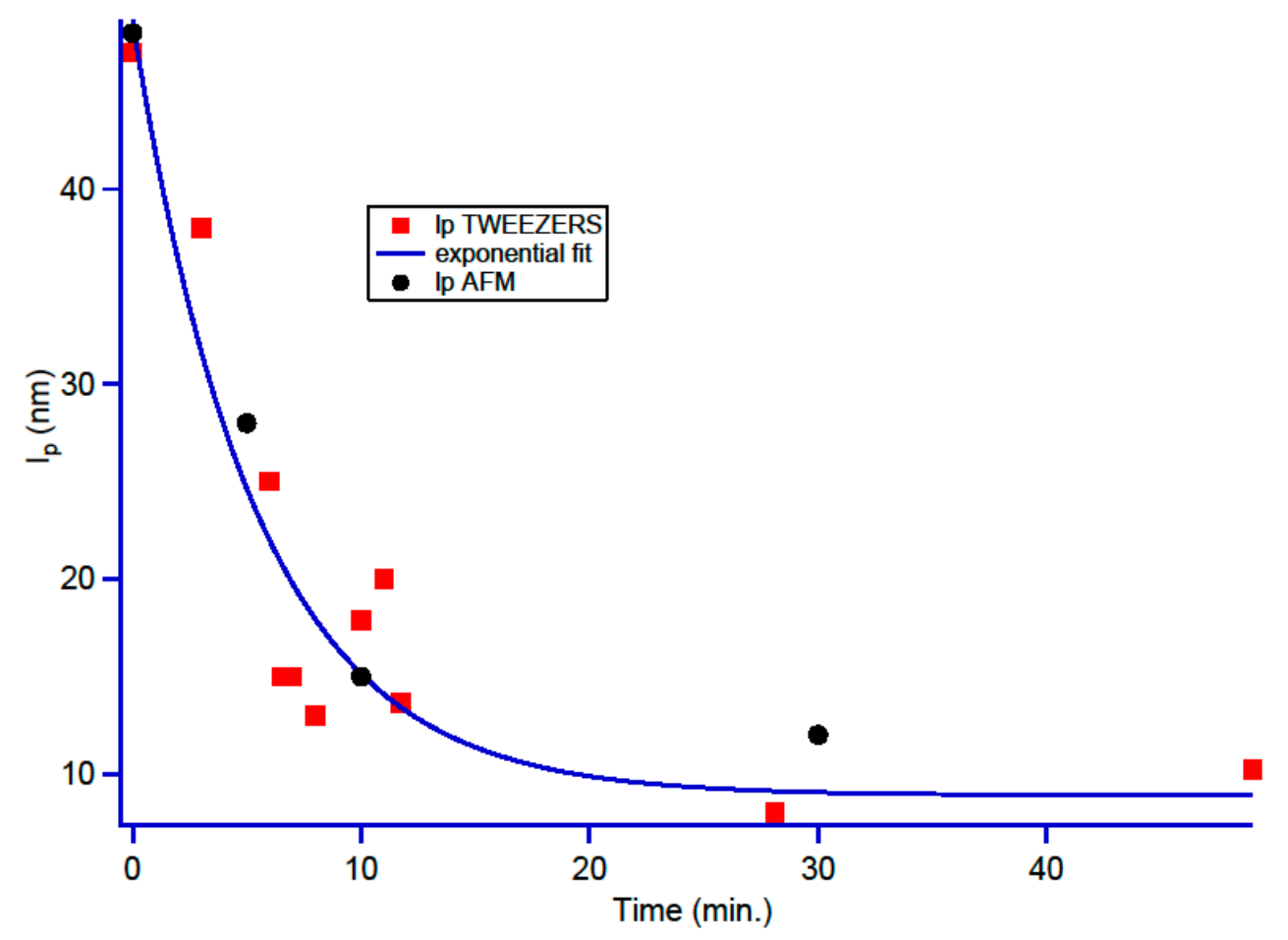

Figure 8. Persistence length decrease as a function of time for the optical tweezers (red dots) and AFM (black dots). An exponential adjustment was added on top of the experimental points to help visualization.

The persistence length decreases continuously from $48 \mathrm{~nm}$ (native DNA in buffer condition) to $10 \mathrm{~nm}$ after $30 \mathrm{~min}$ of incubation with the platinum compound. For easier visualization of the overall scheme, we adjusted these results with an exponential decrease.

The persistence length decrease has been described in the case of the cisplatin $[66,67,70,71]$ and $10 \mathrm{~nm}$ lengths have already been measured in cisplatin compounds [49]. Taking into account the different models established for cisplatin the decrease in the persistence length can be attributed either to the formation of monoadducts that locally changes the DNA skeleton structure or to the formation of diadducts. These diadducts have two possibilities to act on the persistence length either by increasing the number of kinks when intrastrand adducts are formed or by forming micro-loops due to interstrand adducts $[66,67,70,71]$. Nevertheless, Li et al. [71] have compared the persistence lengths of DNA incubated either with transplatin or cisplatin and conclude that the formation of diadducts between the molecule and the DNA strand is necessary to observe persistence lengths as low as the one obtained with 2 Nevertheless, it takes long time for complex 2 to interact with DNA and to form diadducts, which is why the effects are recorded after $20 \mathrm{~h}$. 


\subsection{Long Time Incubation Behavior}

According to the literature, diadducts can be interstrand and, in this case, DNA should show kinks in its structure. These kinks are clearly seen on the AFM images after 40 min of incubation (Figure 9A), but they can also be interstrand. In that case, DNA should form loops with different sizes, which is observed in this case after $40 \mathrm{~min}$. This reaction is quite slow and upon $20 \mathrm{~h}$ incubation, as in Figure 9B, aggregates are visible on the DNA chain.
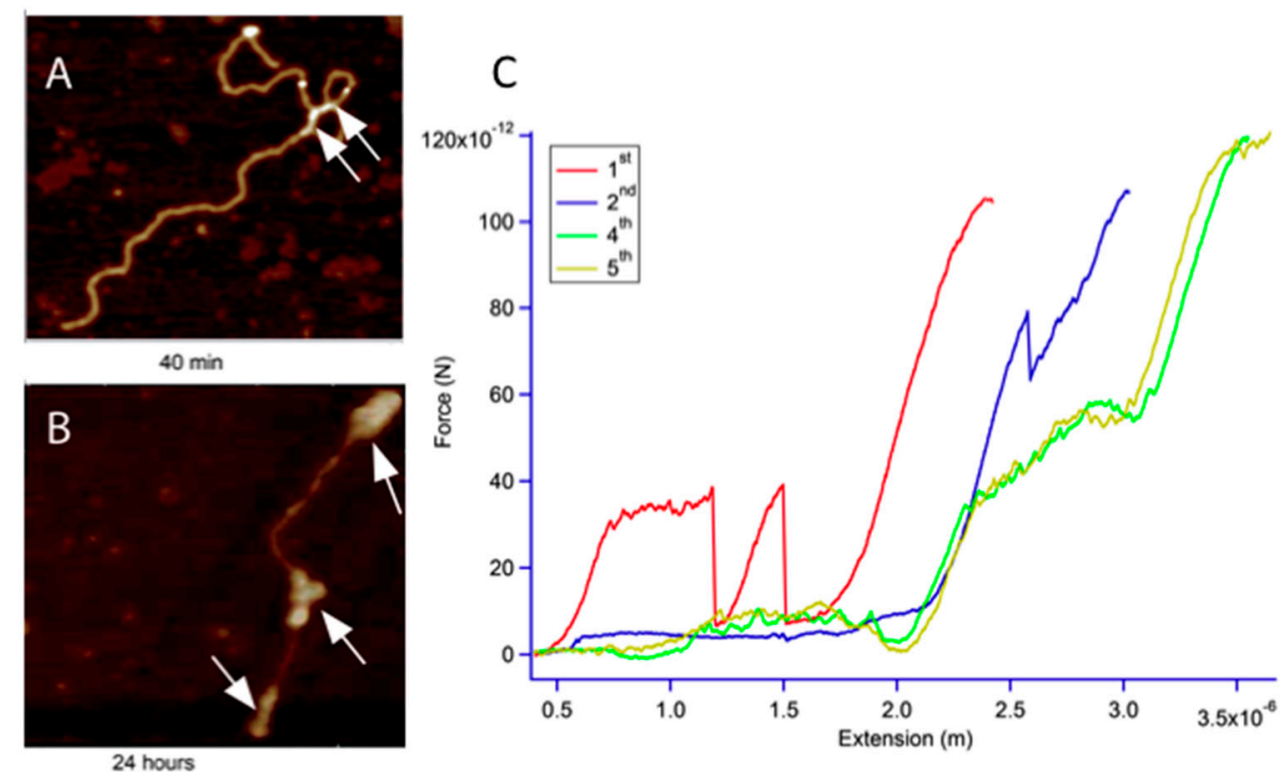

Figure 9. (A) DNA molecule incubated $40 \mathrm{~min}$ with the platinum compound. Interstrand crosslinks appear after $40 \mathrm{~min}$ (arrow). (B) DNA molecule incubated $24 \mathrm{~h}$ with the platinum compound. Compact structures appear (white arrows). (C) Successive force-extension curves on the same DNA molecule after $24 \mathrm{~h}$ incubation with the platinum compounds.

Stretching on these molecules after $20 \mathrm{~h}$ incubation gives rise to a curve that differs from the typical curves presented in Figure 9C. The various curves represent a series of successive force-extension curves obtained on the same molecule. The first curve shows an increase in force after only $0.5 \mu \mathrm{m}$ of extension and reaches a pseudo-plateau at a force starting at $32 \mathrm{pN}$ and ending at $38 \mathrm{pN}$ over an extension of $600 \mathrm{~nm}$. At this extension, an unexpected force drop appears. The force sinks from $38 \mathrm{pN}$ to $8 \mathrm{pN}$ rapidly and corresponds to a win in length which equals $90 \mathrm{~nm}$. The force then increases again following the WLC model till the force reaches $38 \mathrm{pN}$ and a similar drop is observed. Following stretching, the molecule behaves normally except that the molecule does not undergo a B-S transition even at forces as high as $100 \mathrm{pN}$. The second stretching curve goes further in extension which seems to be due to some losses in interaction between the platinum complex and the DNA strand. This curve does not present any transition but around $80 \mathrm{pN}$ a drop appears. This drop is around $23 \mathrm{pN}$ and occurs at a force that is around twice the force needed in previous experiment. Further stretching gave superimposable curves, the full contour length of the DNA molecules was not reached, and a B-S transition appeared. This B-S transition is shorter as the 1.7 full extensions which are expected and the transition is not as cooperative as in naked DNA. This can be seen by the transition forces that normally have a slope close to zero and $\Delta \mathrm{F}$ is around $5 \mathrm{pN}$. In our case, in presence of platinum complexes, the transition starts around $30 \mathrm{pN}$ and ends around $60 \mathrm{pN}$, which gives $\Delta \mathrm{F}=30 \mathrm{pN}$. This behavior has been described for cisplatin by Krautbauer et al. [56]. They reported a $\Delta \mathrm{F}$ value around $40 \mathrm{pN}$ and the transition was starting at $30 \mathrm{pN}$ and ending at $70 \mathrm{pN}$. The 5 th stretching shows a second transition around $120 \mathrm{pN}$ which again was described by Krautbauer et al. This second transition was attributed to the melting of the strands. 


\section{Discussion}

NHC-platinum complex 1 which features an anthracene moiety has been designed with the aim of increasing the overall cytotoxic activity of the system because of potential synergistic effect. The compound was easily synthesized in good yield in one step and was found to be highly stable both in solid state and in solution (DMSO/water). The molecular structure has been unambiguously established by $\mathrm{X}$-ray diffraction studies. Antiproliferative activity of $\mathbf{1}$ was measured $\left(\mathrm{IC}_{50}\right.$, Table 1 ) on a panel of five different human cancer cells (MCF7, HCT116, PC3, SK-OV3, and MRC-5) and one noncancerous cell line EPC, using cisplatin as a reference for the study. The compound showed very high activity with $\mathrm{IC}_{50}$ ranging from 0.01 to $0.08 \mu \mathrm{M}$, which are two orders of magnitude higher than cisplatin activity. This is also much higher than known platinum(II) $\mathrm{N}$-heterocyclic carbene complexes thus confirming the positive impact of the anthracene moiety. Indeed, complexes of type $(\mathrm{NHC}) \mathrm{PtI}_{2}(\mathrm{~L})$ have $\mathrm{IC}_{50}$ at a micromolar range typically from 0.5 to $5 \mu \mathrm{M}[48,54,55,68,72]$.

It is widely recognized that the anticancer activity of cisplatin and related compounds such as oxaliplatin is a consequence of DNA damage further triggering cell death. In vitro DNA binding studies have pointed out the role of such interactions to induce apoptosis in such family of NHC-platinum complexes [73]. In order to gain more insight into the nature of the metal-DNA interaction, a dye pair was used for FRET spectroscopy (complex 2, Figure 2). The anthracene fragment on the backbone of the NHC has been used as a donor fluorophore which efficiently transfers its energy to the dabsyl moiety, thus quenching the anthracene emission. The emission may be recovered upon the release of the dabsyl ligand from the platinum complex thus evidencing the lability of the pyridine ligand in the trans position [68]. Herein, we investigated the luminescence properties of complex 2 in the presence of salmon sperm DNA. The luminescence is visible after few hours and the relative intensity is gradually increasing as a function of time. Overall, these results are consistent with a pyridine-DNA ligand exchange thus leading to the formation of a platinum-DNA adduct upon release of the free pyridine.

To further investigate the interaction of this platinum NHC complex with DNA, single-molecule experiments were performed using either optical tweezers or AFM microscopy in aqueous environment. Both experiments showed clear interaction between the strands and the platinum complex. Analyzing the contour length in both experiments strikingly revealed a two-state behavior during the experiments. At shorter time scales, between 0 and $7 \mathrm{~min}$, the contour length significantly increased by $6 \%$ (from $0.34 \mathrm{~nm} / \mathrm{bp}$ to $0.36 \mathrm{~nm} / \mathrm{bp}$ ). At longer time scales, between 8 to $120 \mathrm{~min}$, and even longer $(24 \mathrm{~h})$, the contour length monotonously decreased from $0.34 \mathrm{~nm} / \mathrm{bp}$ to $0.22 \mathrm{~nm} / \mathrm{bp}$. Anthracene complexes are known to intercalate the base pairs (64), thus we hypothesize this interaction to initiate the inter and intrastrand interactions occurring in both cisplatin and transplatin at longer time scales [64]. The duality in the interactions based on the chemical structure of the compounds, as well as the lability of the pyridine ligand, is in good agreement with a two-state interaction. A monotonous decrease is also observed over time of the persistence length of the DNA molecule from $50 \mathrm{~nm}$ to $12 \mathrm{~nm}$, which is in good agreement with measurements established on cisplatin/DNA complexes [65]. The decrease in persistence length brings the DNA molecule to be more flexible and thus to favor short- and long-distance interactions which, over time, brings the DNA/NHC complex to form compact and dense molecules. This compaction over $12 \mathrm{~h}$ of interaction has been described at the single molecule level in the cisplatin compounds [62]. We performed single-molecule stretching on these dense compounds to characterize the forces involved in this densification. We measured a force of around $40 \mathrm{pN}$ to break part of the interactions and to further be able to stretch the DNA molecule. The successive stretching on the same DNA strand revealed that once these adducts broke, they were not able to form again at the time scale used to perform the successive stretching. This study conducted at the molecular and cellular level shows a strong affinity of these new NHC compounds to interact strongly with the DNA strands and to induce cellular apoptosis at doses that are around 100 times lower than the classical platinum compounds administered in clinics. Although gaps are evident between this molecular study and the in vitro observations and the in vivo effects, it appears that these new NHC complexes have higher cellular toxicity than cisplatin which is commonly used in clinics. 


\section{Material and Methods}

\subsection{NHC-Pt Complexes: Synthesis and Characterization}

NHC platinum complex 1 has been synthesized from the corresponding imidazolium as previously reported [68,72]. The platinum complexes were prepared by reaction of the imidazolium salt in the presence of platinum dichloride, excess $\mathrm{NaI}$ and $\mathrm{K}_{2} \mathrm{CO}_{3}$ in dry pyridine at $100{ }^{\circ} \mathrm{C}$ overnight, under nitrogen atmosphere. The compound was purified by silica chromatography and was recrystallized to get the expected product in 63\% yield. The molecular structure of the Pt complex was unambiguously confirmed by X-ray crystallography. The synthesis of the NHC complex 2 has been previously reported by us [68].

\subsection{DNA and Optical Tweezers}

For the force-extension measurements, we prepared unconstrained DNA molecules functionalized on one end with the biotin and digoxygenin at the other end to allow the attachment to streptavidin-coated beads and the anti-digoxygenin-coated flow cell, respectively [74].

The optical setup and the way to stretch DNA were previously described in different works [74,75]. This DNA construct consists of a construct of a dimer of commercially available plasmid DNA PBR322 (Sigma Aldrich, St. Louis, MO, USA) with a total size of $9.7 \mathrm{kbp}$ and a length of $2.8 \mu \mathrm{m}$ [74]. We incubated $1 \mathrm{ng}$ of this DNA which represents a concentration of reactive base pairs of $5 \mathrm{nM}$. The single-beam trap obtained through a high numerical aperture objective catches the dielectric particle linked to DNA. The other side of the DNA molecule was attached to the coverglass which is moved in a controlled way with a piezoelectric translation stage. All the stretching experiments were performed at a pulling rate of $\sim 500 \mathrm{~nm} / \mathrm{s}$ in $10 \mathrm{mM}$ Hepes.

The obtained force-extension curves were post-analyzed using the modified worm-like chain model described first by Bustamante et al. in 1994 [76].

$$
\mathrm{F}=\left(\frac{\mathrm{k}_{\mathrm{B}} \mathrm{T}}{\mathrm{L}_{\mathrm{p}}}\right)\left[\frac{1}{4\left(1-\mathrm{x} / \mathrm{L}_{0}+\mathrm{F} / \mathrm{k}_{0}\right)^{2}}-\frac{1}{4}+\frac{\mathrm{x}}{\mathrm{L}_{0}}-\frac{\mathrm{F}}{\mathrm{k}_{0}}\right]
$$

where $\mathrm{L}_{\mathrm{p}}$ represents the persistence length, $\mathrm{L}_{0}$ the contour length, $\mathrm{k}_{0}$ the elastic modulus, and $\mathrm{k}_{\mathrm{B}} \mathrm{T}$ the thermal energy.

Another elegant method to follow the lengths changes was described by Baumann et al. [77]. By taking into account only the entropic part of the obtained curve, but for extension $x$ approaching $L_{0}$, the worm-like chain equation can be rewritten as follows:

$$
\frac{\mathrm{x}}{\mathrm{L}_{0}}=1-\frac{1}{2}\left(\frac{\mathrm{kT}}{\mathrm{FL}_{\mathrm{p}}}\right)^{\frac{1}{2}}
$$

Or expressed differently, we get a linear relation between the inverse square root of the force and the applied extension:

$$
\mathrm{F}^{-\frac{1}{2}}=\left(1-\frac{\mathrm{x}}{\mathrm{L}_{0}}\right)\left(\frac{4 \mathrm{~L}_{\mathrm{p}}}{\mathrm{kT}}\right)^{\frac{1}{2}}
$$

\subsection{DNA and AFM}

The DNA used in these experiments was obtained from an EcoRI linearized plasmid PBR322 (Sigma Aldrich, St. Louis, MO, USA). This plasmid is a $4361 \mathrm{bp}$ long DNA that corresponds to a contour length of $1480 \mathrm{~nm}$. DNA was purified after every step using chromatography columns from Qiagen (QIAquick PCR Purification Kit, Venlo, The Netherlands). All DNA preparations were diluted in $1 \mathrm{mM}$ tris- $\mathrm{HCl}$ buffer, $\mathrm{pH} 7$, to a final DNA concentration of $1 \mu \mathrm{g} \cdot \mathrm{mL}^{-1}$. 
To perform experiments on naked DNA, $\mathrm{MgCl}_{2}$ added to the DNA solution to a final concentration of $1 \mu \mathrm{M}$. $200 \mu \mathrm{L}$ of this DNA solution was injected in AFM liquid cell (Brucker, Billerica, MA, USA) and DNA molecules adsorbed onto freshly cleaved mica at room temperature. In the case of the solution containing platinum complex, no $\mathrm{MgCl}_{2}$ was added. DNA and compound 2 were incubated at room temperature for the time decided for the experiment before being injected in the AFM cell following the same procedure as detailed above.

Images were collected using a Nanoscope IIIa (Veeco Inc, New York, NY, US) operated in tapping mode in solution. Ultrasharp, noncontact silicon cantilevers (NanoAndMore, Wetzlar, Germany) with a nominal tip radius of $<10 \mathrm{~nm}$ were driven at oscillation frequencies in the range of $20-26 \mathrm{kHz}$. During AFM imaging, the force was reduced to avoid dragging of DNA by the tip. The scan rate was usually $1.4 \mathrm{~Hz}$. Integral gain was adjusted to give sharp images. Images were taken without online filtering and were subsequently processed only by flattening to remove the background slope. Apparent DNA contour lengths were measured by summing the consecutive distances between the starting and ending positions that are displayed on the image. From AFM images of DNA molecules, we measured end-to-end distance $R$ and the apparent DNA lengths $\mathrm{L}_{0}$.

The rigidity of DNA is often characterized by its persistence length $L_{p}$. It provides a measure of the distance along which the direction of the chain persists before changing its course. Herein, we describe a method for measuring the persistence length of dsDNA in physiological conditions. During adsorption, DNA molecules are transformed from three dimensional (3D) into two dimensional (2D) objects. Two extreme cases were reported: one where the molecules freely equilibrate on the surface, before being trapped in a particular conformation; and one where the molecules adhere without having equilibrated on the substrate, resembling the natural 3D conformation. In the latter case, the conformation of the molecules reflects the history of their approach to the surface and it is, therefore, difficult to distinguish between the intrinsic conformation and those induced upon adsorption. Recently, we have shown that in the case of DNA adsorption in solution, the molecules freely equilibrate on the surface [69]. In this case, it is possible to obtain an ensemble of 2D conformations, which can be related to the true 3D DNA structure as:

$$
\left\langle\mathrm{R}^{2}\right\rangle_{2 \mathrm{D}}=4 \mathrm{~L}_{\mathrm{p}} \mathrm{L}\left(1-\frac{2 \mathrm{~L}_{\mathrm{p}}}{\mathrm{L}}\left(1-\mathrm{e}^{-\frac{\mathrm{L}}{2 \mathrm{~L}_{\mathrm{p}}}}\right)\right)
$$

where $<\mathrm{R}^{2}>$ is the mean square end to end distance of the chain in two dimensions and $\mathrm{L}$ is the contour length. For long chains $<\mathrm{R}^{2}>_{2 \mathrm{D}}=4 \mathrm{~L}_{\mathrm{p}} \times \mathrm{L}$.

\subsection{Luminescence Studies on the Complexes}

Upon excitation of 2 at $368 \mathrm{~nm}$, the fluorophore's emission is quenched by the dabsyl group (i.e., dark quencher of the excitation energy of the anthracene moiety; dabsyl = dimethylaminoazobenzenesulfonyl). The luminescent properties of the anthracene moiety may be recovered upon a release of the dabsyl quencher from the platinum complex (i.e., ligand exchange of the dark quencher trans to the carbene). A solution of 2, dissolved in DMSO, was added to a solution of salmon sperm DNA in water (10 DNA base pairs compared to platinum, $\mathrm{C}_{\mathrm{Pt}}=1.34 \times 10^{-4} \mathrm{M}$ ).

A solution of $\mathbf{1}$, dissolved in DMSO, was added to a solution of salmon sperm DNA in water (1 DNA base pairs compared to 10 or 100 platinum, $\mathrm{C}_{\mathrm{Pt}}=4 \times 10^{-7} \mathrm{M}$ ). The luminescence is expected to increase as the complex intercalates between the DNA base pairs (excitation at $368 \mathrm{~nm}$ ).

\subsection{Evaluation of Cell Viability by MTS Assays}

Samples were prepared by dissolution of the compound in DMSO and dissolution of cisplatin in water) at stock concentrations of $10 \mathrm{mM}$. MCF7, HCT116, PC3, and SK-OV3 cell lines were maintained as monolayers in RPMI 1640 medium supplemented with $10 \%$ fetal calf serum, in the presence of penicillin, streptomycin, and fungizone in $75 \mathrm{~cm}^{2}$ flask under $5 \% \mathrm{CO}_{2}$, while MRC5 and EPC were grown in complete D-MEM medium. Cells were plated in 96-well tissue culture plates in $200 \mu \mathrm{L}$ complete medium at a density of 1000-2500 cells per well and treated $24 \mathrm{~h}$ later with $2 \mu \mathrm{L}$ of compounds 
using a Biomek 3000 automation workstation (Beckman-Coulter, Pasadena, CA, USA). Controls received the same volume of the appropriate vehicle (DMSO or water, $1 \%$ final volume). After $72 \mathrm{~h}$ exposure, MTS reagent (CellTiter $96^{\circledR}$ Aqueous One, Promega, Madison, WI, USA) was added and incubated for $3 \mathrm{~h}$ at $37^{\circ} \mathrm{C}$; the absorbance was monitored at $490 \mathrm{~nm}$ and results expressed as the inhibition of cell proliferation calculated as the ratio [(1-(OD490 treated/OD490 control) $) \times 100]$ in triplicate experiments after subtraction of the blank without cells. Positive controls (cells incubated with a reference drug at its $\mathrm{IC}_{50}$ concentration) were routinely added to check the responsiveness of cells. For $\mathrm{IC}_{50}$ determination (50\% inhibition of cell proliferation), cells were incubated for $72 \mathrm{~h}$ following the same protocol with compound concentrations ranged $5 \mathrm{nM}$ to $100 \mu \mathrm{M}$ in separate duplicate experiments. At these concentrations, no interference with $\mathrm{Pt}$ complexes was noticed at $490 \mathrm{~nm}$.

\section{Conclusions}

In conclusion, we have shown that a platinum diiodo complex stabilized by a pyridine and an $\mathrm{N}$-heterocyclic carbene ligand featuring an anthracenyl moiety has high in vitro antiproliferative activities against several cancer cell lines, with $\mathrm{IC}_{50}$ values below $100 \mathrm{nM}$. The anthracenyl moiety has been used as a luminescent tag to gain more insights into the metal-DNA interactions. We also performed single-cell experiments using either optical tweezers or AFM microscopy, and cisplatin was used as a control since its interaction with DNA has been widely studied. We confirmed the ability of the platinum complex to interact with the DNA strands and revealed a highly compact and dense structure of platinum compounds bridging the DNA strands. Overall, our investigations confirmed that the platinum NHC complex behaves similarly to cisplatin.

Author Contributions: S.B.-L. and S.H. designed research. E.C., G.D., M.B. and S.B.-L. conceived, designed, and performed the chemical experiments. S.H. performed the biological experiments. M.M. performed the AFM experiments and the subsequent analysis. S.H. and S.B.-L. wrote the paper.

Funding: This research was funded by La Ligue Contre le Cancer-Grand-Est and by the University of Strasbourg/CNRS-Program IDEX Interdisciplinaire. E.C., M.B., and G.D. were granted by the French "Ministère de la Recherche".

Acknowledgments: We thank Etienne Borré for valuable preliminary experiments.

Conflicts of Interest: The authors declare no conflict of interest.

\section{References}

1. Rosenberg, B.; Vancamp, L.; Krigas, T. Inhibition of cell division in Escherichia Coli by electrolysis products from a platinum electrode. Nature 1965, 205, 698-699. [CrossRef] [PubMed]

2. Rosenblum, W.I. Erythrocyte Velocity and a Velocity Pulse in Minute Blood Vessels on the Surface of the Mouse Brain. Circ. Res. 1969, 24, 887-892. [CrossRef] [PubMed]

3. Rougier, P.; Zarba, J.J.; Ducreux, M.; Basile, M.; Pignon, J.P.; Mahjoubi, M.; Benahmed, M.; Droz, J.P.; Cvitkovic, E.; Armand, J.P. Phase II study of cisplatin and 120-hour continuous infusion of 5-fluorouracil in patients with advanced pancreatic adenocarcinoma. Ann. Oncol. 1993, 4, 333-336. [CrossRef] [PubMed]

4. Williams, S.D.; Stablein, D.M.; Einhorn, L.H.; Muggia, F.M.; Weiss, R.B.; Donohue, J.P.; Paulson, D.F.; Brunner, K.W.; Jacobs, E.M.; Spaulding, J.T. Immediate adjuvant chemotherapy versus observation with treatment at relapse in pathological stage II testicular cancer. N. Engl. J. Med. 1987, 317, 1433-1438. [CrossRef] [PubMed]

5. Alberts, D.S.; Liu, P.Y.; Hannigan, E.V.; O’Toole, R.; Williams, S.D.; Young, J.A.; Franklin, E.W.; Clarke-Pearson, D.L.; Malviya, V.K.; DuBeshter, B. Intraperitoneal cisplatin plus intravenous cyclophosphamide versus intravenous cisplatin plus intravenous cyclophosphamide for stage III ovarian cancer. N. Engl. J. Med. 1996, 335, 1950-1955. [CrossRef]

6. Wong, E.; Giandomenico, C.M. Current Status of Platinum-Based Antitumor Drugs. Chem. Rev. 1999, 99, 2451-2466. [CrossRef] [PubMed] 
7. Stuart, N.S.; Woodroffe, C.M.; Grundy, R.; Cullen, M.H. Long-term toxicity of chemotherapy for testicular cancer-the cost of cure. Br. J. Cancer 1990, 61, 479-484. [CrossRef] [PubMed]

8. Coates, A.; Dillenbeck, C.F.; McNeil, D.R.; Kaye, S.B.; Sims, K.; Fox, R.M.; Woods, R.L.; Milton, G.W.; Solomon, J.; Tattersall, M.H. On the receiving end-II. Linear analogue self-assessment (LASA) in evaluation of aspects of the quality of life of cancer patients receiving therapy. Eur. J. Cancer Clin. Oncol. 1983, 19, 1633-1637. [CrossRef]

9. Lane, B.R.; Smith, A.K.; Larson, B.T.; Gong, M.C.; Campbell, S.C.; Raghavan, D.; Dreicer, R.; Hansel, D.E.; Stephenson, A.J. Chronic kidney disease after nephroureterectomy for upper tract urothelial carcinoma and implications for the administration of perioperative chemotherapy. Cancer 2010, 116, 2967-2973. [CrossRef]

10. Sonpavde, G.; Goldman, B.H.; Speights, V.O.; Lerner, S.P.; Wood, D.P.; Vogelzang, N.J.; Trump, D.L.; Natale, R.B.; Grossman, H.B.; Crawford, E.D. Quality of pathologic response and surgery correlate with survival for patients with completely resected bladder cancer after neoadjuvant chemotherapy. Cancer 2009, 115, 4104-4109. [CrossRef]

11. Mercs, L.; Albrecht, M. Beyond catalysis: N-heterocyclic carbene complexes as components for medicinal, luminescent, and functional materials applications. Chem. Soc. Rev. 2010, 39, 1903-1912. [CrossRef] [PubMed]

12. Diez-Gonzalez, S. N-Heterocyclic Carbenes: From Laboratory Curiosities to Efficient Synthetic Tools; Royal Society of Chemistry: Cambridge, UK, 2010.

13. Glorius, F.; Bellemin-Laponnaz, S. N-Heterocyclic Carbenes in Transition Metal Catalysis; Springer: Berlin, Germany, 2007; Volume 21.

14. Nolan, S.P. N-Heterocyclic Carbenes in Synthesis; John Wiley: Hoboken, NJ, USA, 2006.

15. Gade, L.H.; Bellemin-Laponnaz, S. Mixed oxazoline-carbenes as stereodirecting ligands for asymmetric catalysis. Coord. Chem. Rev. 2007, 251, 718-725. [CrossRef]

16. Samojłowicz, C.; Bieniek, M.; Grela, K. Ruthenium-based olefin metathesis catalysts bearing N-heterocyclic carbene ligands. Chem. Rev. 2009, 109, 3708-3742. [CrossRef] [PubMed]

17. Poyatos, M.; Mata, J.A.; Peris, E. Complexes with poly(N-heterocyclic carbene) ligands: Structural features and catalytic applications. Chem. Rev. 2009, 109, 3677-3707. [CrossRef] [PubMed]

18. McGuinness, D. Alkene oligomerisation and polymerisation with metal-NHC based catalysts. Dalton Trans. 2009, 35, 6915-6923. [CrossRef] [PubMed]

19. Lin, J.C.Y.; Huang, R.T.W.; Lee, C.S.; Bhattacharyya, A.; Hwang, W.S.; Lin, I.J.B. Coinage metal-N-heterocyclic carbene complexes. Chem. Rev. 2009, 109, 3561-3598. [CrossRef] [PubMed]

20. Jacobsen, H.; Correa, A.; Poater, A.; Costabile, C.; Cavallo, L. Understanding the M(NHC) (NHC=N-heterocyclic carbene) bond. Coord. Chem. Rev. 2009, 253, 687-703. [CrossRef]

21. Arnold, P.L.; Casely, I.J. F-block N-heterocyclic carbene complexes. Chem. Rev. 2009, 109, 3599-3611. [CrossRef]

22. Bellemin-Laponnaz, S.; Dagorne, S. Group 1 and 2 and early transition metal complexes bearing N-heterocyclic carbene ligands: Coordination chemistry, reactivity, and applications. Chem. Rev. 2014, 114, 8747-8774. [CrossRef]

23. César, V.; Bellemin-Laponnaz, S.; Gade, L.H. Chiral N-heterocyclic carbenes as stereodirecting ligands in asymmetric catalysis. Chem. Soc. Rev. 2004, 33, 619-636. [CrossRef]

24. Liu, W.; Gust, R. Metal N-heterocyclic carbene complexes as potential antitumor metallodrugs. Chem. Soc. Rev. 2013, 42, 755-773. [CrossRef] [PubMed]

25. Gautier, A.; Cisnetti, F. Advances in metal-carbene complexes as potent anti-cancer agents. Metallomics 2012, 4, 23-32. [CrossRef]

26. Teyssot, M.-L.; Jarrousse, A.S.; Manin, M.; Chevry, A.; Roche, S.; Norre, F.; Beaudoin, C.; Morel, L.; Boyer, D.; Mahiou, R.; et al. Metal-NHC complexes: A survey of anti-cancer properties. Dalton Trans. 2009, 35, 6894-6902. [CrossRef] [PubMed]

27. Hindi, K.M.; Panzner, M.J.; Tessier, C.A.; Cannon, C.L.; Youngs, W.J. The medicinal applications of imidazolium carbene-metal complexes. Chem. Rev. 2009, 109, 3859-3884. [CrossRef]

28. Hu, C.; Li, X.; Wang, W.; Zhang, R.; Deng, L. Metal-N-heterocyclic carbene complexes as anti-tumor agents. Curr. Med. Chem. 2014, 21, 1220-1230. [CrossRef]

29. Özdemir, İ.; Denizci, A.; Öztürk, H.T.; Çetinkaya, B. Synthetic and antimicrobial studies on new gold(I) complexes of imidazolidin-2-ylidenes. Applied Organomet. Chem. 2004, 18, 318-322. [CrossRef] 
30. Ray, S.; Mohan, R.; Singh, J.K.; Samantaray, M.K.; Shaikh, M.M.; Panda, D.; Ghosh, P. Anticancer and antimicrobial metallopharmaceutical agents based on palladium, gold, and silver N-heterocyclic carbene complexes. J. Am. Chem. Soc. 2007, 129, 15042-15053. [CrossRef]

31. Melaiye, A.; Simons, R.S.; Milsted, A.; Pingitore, F.; Wesdemiotis, C.; Tessier, C.A.; Youngs, W.J. Formation of water-soluble pincer silver(I)-carbene complexes: A novel antimicrobial agent. J. Med. Chem. 2004, 47, 973-977. [CrossRef]

32. Melaiye, A.; Sun, Z.; Hindi, K.; Milsted, A.; Ely, D.; Reneker, D.H.; Tessier, C.A.; Youngs, W.J. Silver(I)-Imidazole Cyclophane gem -Diol Complexes Encapsulated by Electrospun Tecophilic Nanofibers: Formation of Nanosilver Particles and Antimicrobial Activity. J. Am. Chem. Soc. 2005, 127, 2285-2291. [CrossRef]

33. Hindi, K.M.; Siciliano, T.J.; Durmus, S.; Panzner, M.J.; Medvetz, D.A.; Reddy, D.V.; Hogue, L.A.; Hovis, C.E.; Hilliard, J.K.; Mallet, R.J.; et al. Synthesis, stability, and antimicrobial studies of electronically tuned silver acetate N-heterocyclic carbenes. J. Med. Chem. 2008, 51, 1577-1583. [CrossRef]

34. Panzner, M.J.; Deeraksa, A.; Smith, A.; Wright, B.D.; Hindi, K.M.; Kascatan-Nebioglu, A.; Torres, A.G.; Judy, B.M.; Hovis, C.E.; Hilliard, J.K.; et al. Synthesis and in vitro Efficacy Studies of Silver Carbene Complexes on Biosafety Level 3 Bacteria. Eur. J. Inorg. Chem. 2009, 2009, 1739-1745. [CrossRef]

35. Panzner, M.J.; Hindi, K.M.; Wright, B.D.; Taylor, J.B.; Han, D.S.; Youngs, W.J.; Cannon, C.L. A theobromine derived silver N-heterocyclic carbene: Synthesis, characterization, and antimicrobial efficacy studies on cystic fibrosis relevant pathogens. Dalton Trans. 2009, 35, 7308-7313. [CrossRef]

36. Patil, S.; Claffey, J.; Deally, A.; Hogan, M.; Gleeson, B.; Menéndez Méndez, L.M.; Müller-Bunz, H.; Paradisi, F.; Tacke, M. Synthesis, Cytotoxicity and Antibacterial Studies of $p$-Methoxybenzyl-Substituted and Benzyl-Substituted N-Heterocyclic Carbene-Silver Complexes. Eur. J. Inorg. Chem. 2010, 2010, 1020-1031. [CrossRef]

37. Roland, S.; Jolivalt, C.; Cresteil, T.; Eloy, L.; Bouhours, P.; Hequet, A.; Mansuy, V.; Vanucci, C.; Paris, J.M. Investigation of a series of silver-N-heterocyclic carbenes as antibacterial agents: Activity, synergistic effects, and cytotoxicity. Chem. Eur. J. 2011, 17, 1442-1446. [CrossRef]

38. Cetinkaya, B.; Cetinkaya, E.; Küçükbay, H.; Durmaz, R. Antimicrobial activity of carbene complexes of rhodium(I) and ruthenium(II). Arzneimittelforschung 1996, 46, 821-823.

39. Cetinkaya, B.; Ozdemir, I.; Binbaşioğlu, B.; Durmaz, R.; Günal, S. Antibacterial and antifungal activities of complexes of ruthenium (II). Arzneimittelforschung 1999, 49, 538-540. [CrossRef]

40. Weaver, J.; Gaillard, S.; Toye, C.; Macpherson, S.; Nolan, S.P.; Riches, A. Cytotoxicity of gold(I) N-heterocyclic carbene complexes assessed by using human tumor cell lines. Chem. Eur. J. 2011, 17, 6620-6624. [CrossRef]

41. Lemke, J.; Pinto, A.; Niehoff, P.; Vasylyeva, V.; Metzler-Nolte, N. Synthesis, structural characterisation and anti-proliferative activity of NHC gold amino acid and peptide conjugates. Dalton Trans. 2009, 35, 7063-7070. [CrossRef]

42. Horvath, U.E.I.; Bentivoglio, G.; Hummel, M.; Schottenberger, H.; Wurst, K.; Nell, M.J.; van Rensburg, C.E.J.; Cronje, S.; Raubenheimer, H.G. A cytotoxic bis(carbene)gold(I) complex of ferrocenyl complexes: Synthesis and structural characterisation. New J. Chem. 2008, 32, 533-539. [CrossRef]

43. Jellicoe, M.M.; Nichols, S.J.; Callus, B.A.; Baker, M.V.; Barnard, P.J.; Berners-Price, S.J.; Whelan, J.; Yeoh, G.C.; Filipovska, A. Bioenergetic differences selectively sensitize tumorigenic liver progenitor cells to a new gold(I) compound. Carcinogenesis 2008, 29, 1124-1133. [CrossRef]

44. Medvetz, D.A.; Hindi, K.M.; Panzner, M.J.; Ditto, A.J.; Yun, Y.H.; Youngs, W.J. Anticancer Activity of Ag(I) N-Heterocyclic Carbene Complexes Derived from 4,5-Dichloro-1H-Imidazole. Met. Based Drugs 2008, 2008, 384010. [CrossRef]

45. Teyssot, M.L.; Jarrousse, A.S.; Chevry, A.; De Haze, A.; Beaudoin, C.; Manin, M.; Nolan, S.P.; Díez-González, S.; Morel, L.; Gautier, A. Toxicity of copper(I)-NHC complexes against human tumor cells: Induction of cell cycle arrest, apoptosis, and DNA cleavage. Chem. Eur. J. 2009, 15, 314-318. [CrossRef]

46. Wang, C.H.; Shih, W.C.; Chang, H.C.; Kuo, Y.Y.; Hung, W.C.; Ong, T.G.; Li, W.S. Preparation and characterization of amino-linked heterocyclic carbene palladium, gold, and silver complexes and their use as anticancer agents that act by triggering apoptotic cell death. J. Med. Chem. 2011, 54, 5245-5249. [CrossRef] [PubMed] 
47. Ray, L.; Barman, S.; Shaikh, M.M.; Ghosh, P. Highly convenient amine-free sonogashira coupling in air in a polar mixed aqueous medium by trans- and cis-[(NHC)2PdX2] $(\mathrm{X}=\mathrm{Cl}, \mathrm{Br})$ complexes of N/O-functionalized N-heterocyclic carbenes. Chem. Eur. J. 2008, 14, 6646-6655. [CrossRef] [PubMed]

48. Skander, M.; Retailleau, P.; Bourrié, B.; Schio, L.; Mailliet, P.; Marinetti, A. N-heterocyclic carbene-amine Pt(II) complexes, a new chemical space for the development of platinum-based anticancer drugs. J. Med. Chem. 2010, 53, 2146-2154. [CrossRef] [PubMed]

49. Wai-Yin Sun, R.; Lok-Fung Chow, A.; Li, X.H.; Yan, J.J.; Sin-Yin Chui, S.; Che, C.M. Luminescent cyclometalated platinum(ii) complexes containing $\mathrm{N}$-heterocyclic carbene ligands with potent in vitro and in vivo anti-cancer properties accumulate in cytoplasmic structures of cancer cells. Chem. Sci. 2011, 2, 728. [CrossRef]

50. Dasari, S.; Bernard Tchounwou, P. Cisplatin in cancer therapy: Molecular mechanisms of action. Eur. J. Pharmacol. 2014, 740, 364-378. [CrossRef]

51. Hu, D.; Yang, C.; Lok, C.N.; Xing, F.; Lee, P.Y.; Fung, Y.M.E.; Jiang, H.; Che, C.M. An Antitumor Bis(N-Heterocyclic Carbene)Platinum(II) Complex That Engages Asparagine Synthetase as an Anticancer Target. Angew. Chem. Int. Ed. 2019, 58, 10914-10918. [CrossRef]

52. Todd, R.C.; Lippard, S.J. Inhibition of transcription by platinum antitumor compounds. Metallomics 2009, 1, 280. [CrossRef]

53. Chu, G. Cellular responses to cisplatin. The roles of DNA-binding proteins and DNA repair. J. Biol. Chem. 1994, 269, 787-790.

54. Chekkat, N.; Dahm, G.; Chardon, E.; Wantz, M.; Sitz, J.; Decossas, M.; Lambert, O.; Frisch, B.; Rubbiani, R.; Gasser, G.; et al. N-Heterocyclic Carbene-Polyethylenimine Platinum Complexes with Potent in Vitro and in Vivo Antitumor Efficacy. Bioconjug. Chem. 2016, 27, 1942-1948. [CrossRef]

55. Wantz, M.; Bouché, M.; Dahm, G.; Chekkat, N.; Fournel, S.; Bellemin-Laponnaz, S. N-Heterocyclic Carbene-Polyethyleneimine (PEI) Platinum Complexes Inducing Human Cancer Cell Death: Polymer Carrier Impact. Int. J. Mol. Sci. 2018, 19, 3472. [CrossRef] [PubMed]

56. Krautbauer, R.; Pope, L.H.; Schrader, T.E.; Allen, S.; Gaub, H.E. Discriminating small molecule DNA binding modes by single molecule force spectroscopy. FEBS. Lett. 2002, 510, 154-158. [CrossRef]

57. Sischka, A.; Toensing, K.; Eckel, R.; Wilking, S.D.; Sewald, N.; Ros, R.; Anselmetti, D. Molecular Mechanisms and Kinetics between DNA and DNA Binding Ligands. Biophys. J. 2005, 88, 404-411. [CrossRef] [PubMed]

58. Mihailovic, A.; Vladescu, I.; McCauley, M.; Ly, E.; Williams, M.C.; Spain, E.M.; Nuñez, M.E. Exploring the Interaction of Ruthenium(II) Polypyridyl Complexes with DNA Using Single-Molecule Techniques. Langmuir 2006, 22, 4699-4709. [CrossRef] [PubMed]

59. Wang, M.D.; Yin, H.; Landick, R.; Gelles, J.; Block, S.M. Stretching DNA with optical tweezers. Biophys. J. 1997, 72, 1335. [CrossRef]

60. Johnson, N.P.; Hoeschele, J.D.; Rahn, R.O. Kinetic analysis of the in vitro binding of radioactive cis- and trans-dichlorodiammineplatinum(II) to DNA. Chem. Biol. Interact. 1980, 30, 151-169. [CrossRef]

61. Gao, E.J.; Sun, T.D.; Liu, S.H.; Ma, S.; Wen, Z.; Wang, Y.; Zhu, M.C.; Wang, L.; Gao, X.N.; Guan, F.; et al. Synthesis, characterization, interaction with DNA and cytotoxicity in vitro of novel pyridine complexes with Zn(II). Eur. J. Med. Chem. 2010, 45, 4531-4538. [CrossRef]

62. García, B.; Garcia-Tojal, J.; Ruiz, R.; Gil-García, R.; Ibeas, S.; Donnadieu, B.; Leal, J.M. Interaction of the DNA bases and their mononucleotides with pyridine-2-carbaldehyde thiosemicarbazonecopper(II) complexes. Structure of the cytosine derivative. J. Inorg. Biochem. 2008, 102, 1892-1900. [CrossRef]

63. Tanious, F.A.; Jenkins, T.C.; Neidle, S.; Wilson, W.D. Substituent position dictates the intercalative DNA-binding mode for anthracene-9, 10-dione antitumor drugs. Biochemistry 1992, 31, 11632-11640. [CrossRef]

64. Cox, J.W.; Berners-Price, S.J.; Davies, M.S.; Qu, Y.; Farrell, N. Kinetic analysis of the stepwise formation of a long-range DNA interstrand cross-link by a dinuclear platinum antitumor complex: Evidence for aquated intermediates and formation of both kinetically and thermodynamically controlled conformers. J. Am. Chem. Soc. 2001, 123, 1316-1326. [CrossRef]

65. Hou, X.M.; Zhang, X.H.; Wei, K.J.; Ji, C.; Dou, S.X.; Wang, W.C.; Li, M.; Wang, P.Y. Cisplatin induces loop structures and condensation of single DNA molecules. Nucleic Acids Res. 2009, 37, 1400-1410. [CrossRef] [PubMed]

66. Crisafuli, F.A.P.; Cesconetto, E.C.; Ramos, E.B.; Rocha, M.S. DNA-cisplatin binding mechanism peculiarities studied with single molecule stretching experiments. Appl. Phys. Lett. 2012, 100, 083701. [CrossRef] 
67. Chen, Y.Z.; Zhang, Y.; Prohofsky, E.W. Binding stability of a cross-linked drug: Calculation of an anticancer drug cisplatin-DNA complex. Phys. Rev. E 1997, 55, 5843-5848. [CrossRef]

68. Chardon, E.; Dahm, G.; Guichard, G.; Bellemin-Laponnaz, S. Exploring nitrogen ligand diversity in trans-N-heterocyclic carbene-amine platinum complexes: Synthesis, characterization, and application to fluorescence. Chem. Asian J. 2013, 8, 1232-1242. [CrossRef] [PubMed]

69. Mantelli, S.; Muller, P.; Harlepp, S.; Maaloum, M. Conformational analysis and estimation of the persistence length of DNA using atomic force microscopy in solution. Soft Matter 2011, 7, 3412. [CrossRef]

70. Yan, J.; Marko, J.F. Effects of DNA-distorting proteins on DNA elastic response. Phys. Rev. E 2003, 68, 011905. [CrossRef]

71. Li, W.; Sun, Z.Q.; Xie, P.; Dou, S.X.; Wang, W.C.; Wang, P.Y. Elastic response and length change of single DNA molecules induced by a combination of cisplatin and transplatin. Phys. Rev. E 2012, 85, 021918. [CrossRef]

72. Chardon, E.; Dahm, G.; Guichard, G.; Bellemin-Laponnaz, S. Derivatization of Preformed Platinum N-Heterocyclic Carbene Complexes with Amino Acid and Peptide Ligands and Cytotoxic Activities toward Human Cancer Cells. Organometallics 2012, 31, 7618-7621. [CrossRef]

73. Chtchigrovsky, M.; Eloy, L.; Jullien, H.; Saker, L.; Ségal-Bendirdjian, E.; Poupon, J.; Bombard, S.; Cresteil, T.; Retailleau, P.; Marinetti, A. Antitumor trans-N-heterocyclic carbene-amine-Pt(II) complexes: Synthesis of dinuclear species and exploratory investigations of DNA binding and cytotoxicity mechanisms. J. Med. Chem. 2013, 56, 2074-2086. [CrossRef]

74. Klajner, M.; Hebraud, P.; Sirlin, C.; Gaiddon, C.; Harlepp, S. DNA Binding to an Anticancer Organo-Ruthenium Complex. J. Phys. Chem. B 2010, 114, 14041-14047. [CrossRef] [PubMed]

75. Drobczynski, S.; Hebraud, P.; Munch, J.P.; Harlepp, S. Design and realization of a high-stability optical tweezer. Opt. Eng. 2009, 48, 113601.

76. Bustamante, C.; Marko, J.; Siggia, E.; Smith, S. Entropic elasticity of lambda-phage DNA. Science 1994, 265, 1599-1600. [CrossRef] [PubMed]

77. Baumann, C.G.; Smith, S.B.; Bloomfield, V.A.; Bustamante, C. Ionic effects on the elasticity of single DNA molecules. Proc. Nat. Acad. Sci. USA 1997, 94, 6185-6190. [CrossRef] [PubMed] 